\title{
Assessing framing of uncertainties in water management practice
}

Nicola Isendahl ${ }^{1}$, Art Dewulf ${ }^{2}$, Marcela Brugnach ${ }^{3}$, Greet François ${ }^{4}$, Sabine Möllenkamp ${ }^{5}$, Claudia Pahl-Wostl ${ }^{6}$

${ }^{1,3,5,6}$ Institute of Environmental Systems Research (USF), University of Osnabrück, Germany

${ }^{2}$ Public Administration and Policy Group,

Wageningen University, Netherlands

${ }^{4}$ Research Group for Work, Organisational and Personnel Psychology

(WOPP), Catholic University of Leuven, Belgium

\section{Abstract}

The importance of problem framing in relation with environmental problems has been stated in various scientific contributions. In this paper we intend to relate it to the issue of uncertainties in water management. Dealing with uncertainties in water management is an important issue and will increase to be so in light of global changes, in particular climate change. To know how uncertainties are framed in water management practice then is important in order to evaluate strategies for dealing with these uncertainties. With the aim of identifying what are important parameters for the framing of uncertainties in water management practice, in this paper we analyze uncertainty situations described by decision-makers in water management. The analysis builds on a series of "Uncertainty Dialogues" carried out within the NeWater project with water managers in the Rhine, Elbe and Guadiana basins in 2006. During these dialogues, representatives of these river basins were asked what uncertainties they en- 
countered in their professional work life and how they confronted them. Analysing these dialogues we identified several important parameters of how uncertainties get framed. Our assumption is that making framing of uncertainty explicit will allow for better dealing with the respective uncertainty situations. In order to get a broader picture of the framing of an uncertainty we therefore suggest to add a third axis to the uncertainty matrix developed earlier by Brugnach et al. (2007) detailing on the relation of actors towards an uncertainty situation. This axis is assembled from the parameters identified in this paper.

\section{Introduction}

Dealing with uncertainties in water management is an important issue and will increase to be so in light of global changes, in particular climate change. So far, however, uncertainties in water management have mostly been discussed in scientific analyses. Little is known about how people in water management practice tackle the issue of uncertainties. In the last years, the importance of the human dimension of uncertainty has been more and more acknowledged and emphasized in the sense that uncertainties are no external and objective phenomena but have to be seen in relation with the people involved (e.g. Brugnach et al. 2007, Klauer and Brown 2004, van Asselt and Rotmans 2002, Friedmann et al. 1999). We build here on the work of Brugnach et al. (2007) who speak of uncertainty as a relational property.

This connects well with the importance of problem framing in relation with environmental problems that has been stated lately in various scientific contributions (cf. e.g. Gray 2003, Pahl-Wostl et al. 2007). In this paper we intend to relate the concept of uncertainties and framing for the area of water management.

Special attention is drawn to the uncertainty matrix (UM) developed by Brugnach et al. (2007) where multiple knowledge frames are included as a specific kind of uncertainty, apart from inherent unpredictability and incomplete knowledge. In that way, we are concerned with a double use of framing: On the one hand within the uncertainty matrix which includes the issue of multiple frames as a 
separate kind of uncertainty and on the other hand in a more general way, beyond the matrix, in the sense that all uncertainties are framed depending on the point of view, interests, experiences etc. of the person dealing with an uncertainty.

For the first one of multiple frames one could think of the question or uncertainty of how the EU Water Framework Directive (WFD) should be implemented where different actors or administrative units may have different views on or approaches to. For the more general sense of framing then, the question of the implementation of the WFD by one actor may be considered as a problem of lack of knowledge about methods how to implement it whereas by another it may be framed as a problem of multiple frames on its implementation.

The analysis in this paper is based on dialogues on uncertainty that were held in several case studies of the project NeWater (New Approached to Adaptive Management under Uncertainty) in early summer 2006 and where the UM was applied (NeWater internal documents). Based on these dialogues that rendered examples of uncertainties practitioners in water management feel they have to deal with in their professional work life we discuss in this paper what may be important parameters in the framing of uncertainties in water management practice. Our assumption is that making framing of uncertainty explicit allows for better dealing with the respective uncertainty situations, particularly in multi-actor constellations as typically is the case in water resources management.

As a theoretical basis for the analysis of framing of uncertainties we give a short introduction to the concepts of framing and uncertainty as used in this paper. Though originally not conceived for that purpose we analyze the use of the UM as a tool for assessing the framing of uncertainties, drawing on the advantages, disadvantages and challenges in using it. We then illustrate further facets of uncertainty by analyzing details of the uncertainty situations reported in the Uncertainty Dialogues. We thereby derive a set of parameters that seem to be important in the framing of uncertainties and reflect on the character of uncertainty. By assessing these parameters of the character of uncertainty (PCU) a richer picture of the framing of an uncertainty may be achieved which could be drawn from when analyzing and evaluating strategies for dealing with uncertain situations. 
We suggest adding the PCU as a third axis to the uncertainty matrix. In the final section we discuss aspects of usefulness and applicability of the identified parameters of uncertainty for water management.

\section{Conceptual background}

As a theoretical basis for the analysis of framing of uncertainties we give a short introduction to the concepts and definitions of framing and uncertainty as used in this paper.

\section{Framing}

There are a lot of concepts around framing and frames which are discussed controversially in various disciplines and contexts. Definitions vary and often the terms are used in connection with other similarly vague terms such as perspective or world view (cf. e.g. Dewulf et al. 2005, Kickert and Klijn et al. 1997, Schön and Rein 1994, van Asselt and Rotmans 2000).

For this analysis, we stick to the term 'framing' and abstain from using other terms such as 'frames' or 'perspectives'. We define framing as the way mental models are applied to a certain (action) situation. With mental model we refer to "a relatively enduring internal abstraction of an external system to aid and govern activity" (after Doyle and Ford 1998:17).

Due to their personal, educational and cultural backgrounds people have a restricted view on real world phenomena or action situations. That means they cannot and do not consider all details and information of a certain situation but observe selectively as to what is in their interest and concern. Consequently they perceive only those parts they have drawn their attention to. This information is processed and translated into strategies to deal with the respective situation. This process of selective observation and consequent perception usually does not start from zero but most often is related to a certain outcome of some former action. So the process is iterated permanently as actions are taken and an action situation evolves. (Weick 1995) 
Emphasizing the importance of the process of framing we here draw on the interactional approach of Dewulf et al. (2005: 5) which focuses on interactive production of meaning over a certain time. Within our analysis, process refers to the fact that the reported uncertainties have been framed through interaction between the participants of the Uncertainty Dialogues, within the session but particularly through interaction with other actors in their daily practice time before the meeting. Hence, in this paper we are not able to study that preceding process but consider the reported uncertainties as a result of an interactive framing process, captured at a certain point in time through the dialogues. This is different from the cognitive approach of framing (cf. Dewulf et al. 2005) relating to structures or schemas of individuals which may be compared to mental models as Doyle and Ford (1998) define them.

\section{Uncertainty}

In this paper uncertainty is defined as a "situation in which there is not a unique and complete understanding of the system to be managed" (Brugnach et al. 2007). This relates to the quality of information of an event or action as well as to information about the behaviour and interest of other actors that are possibly involved in the situation. It may simply refer to a lack of knowledge or to an ambiguous situation where different approaches and solutions may be conceived. Brugnach et al. applied this approach in a matrix on uncertainty (UM). The matrix provides a categorization of uncertainties by the type of knowledge relationship and the object of uncertainty. It distinguishes between three types of knowledge relationships that are assumed to be established among an actor and an object. Those are unpredictability, incomplete knowledge and multiple knowledge frames. Each of the three knowledge relationships can refer to different objects of uncertainty within the natural, technical and social system.

The uncertainty matrix was developed in order to allow for capturing uncertainties in natural resources management in a broader way, particularly including aspects of multiple frames and of social system uncertainties in a more explicit and systematic way (ibidem). The objective further was to design a rather simple structure that could also be referred to and used by practitioners in the field of 
natural resources management. Through the Uncertainty Dialogues the matrix was tested for its application in practice in the context of water management.

Table 1 Uncertainty Matrix (Brugnach et al. 2007)

\begin{tabular}{|c|c|c|c|}
\hline $\begin{array}{r}\text { Type of } \\
\text { knowledge } \\
\text { relationship }\end{array}$ & $\begin{array}{l}\text { Incomplete knowledge } \\
\text { - lack of information } \\
\text { - unreliable informa- } \\
\text { tion } \\
\text { - lack of theoretical } \\
\text { understanding } \\
\text { - ignorance }\end{array}$ & $\begin{array}{l}\text { Unpredictability } \\
\text { (unpredictable } \\
\text { system behaviour) }\end{array}$ & $\begin{array}{l}\text { Multiple knowledge } \\
\text { frames } \\
\text { - different and/or } \\
\text { conflicting ways of } \\
\text { understanding the } \\
\text { system } \\
\text { - different values } \\
\text { and beliefs }\end{array}$ \\
\hline $\begin{array}{l}\text { Natural system } \\
\text { - climate impacts } \\
\text { - water quantity } \\
\text { - water quality } \\
\text { - ecosystem } \\
\text { - ... }\end{array}$ & $\begin{array}{l}\text { Incomplete knowledge } \\
\text { about the natural sys- } \\
\text { tem } \\
\text { E.g. unreliable meas- } \\
\text { urements of water lev- } \\
\text { els? }\end{array}$ & $\begin{array}{l}\text { Unpredictable be- } \\
\text { haviour of the natu- } \\
\text { ral system } \\
\text { E.g. what will be } \\
\text { the highest water } \\
\text { level next year? }\end{array}$ & $\begin{array}{l}\text { Multiple knowledge } \\
\text { frames about the } \\
\text { natural system } \\
\text { E.g. is the main } \\
\text { problem in this basin } \\
\text { the water quantity or } \\
\text { ecosystem status? }\end{array}$ \\
\hline $\begin{array}{l}\text { Technical system } \\
\text { - infrastructure } \\
\text { - technologies } \\
\text { - innovations } \\
\text { - ... }\end{array}$ & $\begin{array}{l}\text { Incomplete knowledge } \\
\text { about the technical } \\
\text { system } \\
\text { E.g. to what water } \\
\text { level will this dike re- } \\
\text { sist? }\end{array}$ & $\begin{array}{l}\text { Unpredictable be- } \\
\text { haviour of the } \\
\text { technical system. } \\
\text { E.g. what will be } \\
\text { the side effects of } \\
\text { technology X? }\end{array}$ & $\begin{array}{l}\text { Multiple knowledge } \\
\text { frames about the } \\
\text { technical system } \\
\text { E.g. should we raise } \\
\text { dikes or create flood } \\
\text { plains? }\end{array}$ \\
\hline $\begin{array}{l}\text { Social system } \\
\text { - } \quad \text { organizational } \\
\text { context } \\
\text { - stakeholders } \\
\text { - econ. aspects } \\
\text { - political aspects } \\
\text { - legal aspects } \\
\text { - ... }\end{array}$ & $\begin{array}{l}\text { Incomplete knowledge } \\
\text { about the social system } \\
\text { E.g. what are the eco- } \\
\text { nomical impacts of a } \\
\text { flood for the different } \\
\text { stakeholders? }\end{array}$ & $\begin{array}{l}\text { Unpredictable be- } \\
\text { haviour of the so- } \\
\text { cial system } \\
\text { E.g. how strong } \\
\text { will the reaction of } \\
\text { stakeholders be at } \\
\text { the next flood? }\end{array}$ & $\begin{array}{l}\text { Multiple knowledge } \\
\text { frames about the so- } \\
\text { cial system } \\
\text { E.g. do we need to } \\
\text { impose insurance } \\
\text { against floods or } \\
\text { adapt the legal regu- } \\
\text { lations about spatial } \\
\text { planning? }\end{array}$ \\
\hline
\end{tabular}




\section{Methods}

The empirical part of this paper is based on the "Uncertainty Dialogues" carried out in case studies of the project NeWater, New Approaches to Adaptive Water Management under Uncertainty, in May 2006 (NeWater internal report 2007)1. Participants were water managers, mostly representatives of the water departments of public administration or water management associations in the river basins of the Wupper (Germany) and the Kromme Rijn (Netherlands) as subbasins of the Rhine, the Guadiana (Spain), and the Elbe (Germany and Czech Republic). In the dialogues they were asked to identify uncertainties they encountered in their professional work life and to explain the way they dealt or would deal with them.

Where possible the dialogues were held as a multi-actor group meeting (Wupper and Kromme Rijn) with about three to five participants and else separately in contact with the respective water management organisations (Guadiana and Elbe). The discussions lasted about two hours on the average and were conducted in a semistructured way along the uncertainty matrix (UM). Moderation of the discussion was performed by NeWater staff (all of them authors of this paper). The meetings mostly took place in the participants' native language with exception of the Elbe where the meetings were basically held in English. The evaluation in this paper is based on audio files, transcripts and notes during the Uncertainty Dialogues, particularly those of the Wupper, Kromme Rijn, Guadiana and Elbe Usti. The latter were all recorded and fully transcribed. Notes were taken during all of the dialogues. For the analysis the full length of each meeting, that is transcript and notes, was taken into account. Where necessary, quotations were translated into English to the best knowledge of the authors of this paper. All citations of this paper were cross-checked with the respective stakeholders. They do not necessarily reflect the opinion of the related organisation but their personal views. (NeWater internal reports 2007)

\footnotetext{
${ }^{1}$ For more general information on the NeWater project: www.newater.info
} 
As the examples of the analysis refer to the discussions during the Uncertainty Dialogues they reflect the situation at that point of time and no dynamic representation of the framing of uncertainties.

\section{Assessing framing of uncertainties}

In this chapter we will first analyze the options for using the uncertainty matrix (UM). We will go on with a more detailed description of uncertainty situations encountered during the Uncertainty Dialogues and conclude with a proposition for an extension of the UM.

\subsection{The uncertainty matrix as a tool for analysis of framing?}

The UM enabled a structured way to approach the issue of uncertainty in water management practice, and though within limits allows for a comparison between case studies.

For the participants it was possible to understand the matrix rather easily and apply it to their work life and experiences. For most of them it was the first time to approach uncertainties in water management in an encompassing and structured way. The use of the uncertainty matrix thus offered a new and more structured way of thinking.

One purpose of the Uncertainty Dialogues was to locate the examples from the water managers in the uncertainty matrix. This occurred either directly by the participants during the meetings or by the moderators during or after the meeting. One result from that was that the foci of attention in the case studies concerning the allocation of the uncertainty examples to the matrix differed (NeWater internal report 2007). It was striking that the location of the identified uncertainties in the matrix showed different emphasis in each of the dialogue groups. Some groups mainly referred to uncertainties in the area of natural and technical issues, others emphasised uncertainties in the social parts and in some discussions the emphasis on single cells was quite salient. 
The reasons for that may be the different contexts of the investigated case studies, the different backgrounds of the participants, the fact that some meetings were individual discussions whereas others were group meetings. Multiple reasons are plausible. Where we cannot assess the concrete reasons the differences in foci nonetheless indicate the differences in framing of the uncertainty situations. Adding to that argument is the observation that the examples were not always easy to allocate clearly to one cell. The ways of allocating an uncertainty situation to the cells proved to be highly disputable in some of the group meetings during the dialogues.

Moreover, often the borders between the cells for allocating one example were blurred respectively reflected the emphasis or interest of the person allocating the uncertainty situation which often comprised different aspects, that is cells. These findings also indicate likelihood for discrepancies between practitioners' and scientists' allocation and hence framing of uncertainties. Hence, it may be interesting to investigate on somebody's reason for allocating an example to a specific cell.

The structured way of approaching the issue of uncertainty in water management practice with help of the UM may however be a disadvantage for the use of it for the assessment of framings of uncertainty. In practice people often have a more intuitive approach towards dealing with issues including uncertainty. When aiming at getting a more complete view on the framing of uncertainties in water management practice the use of the uncertainty matrix therefore may be too structured as approach. This however, is then rather inherent in the method than in the conceptual matrix itself since the latter could still be used for ex post classification of examples elicited by a more open approach. However, for purposes of analyzing the framing of uncertainties this approach may be less adequate since it would be distorted by the intervention of the allocating process. Another adversarial point in using the uncertainty matrix for purposes of analyzing framing is that the criteria of the matrix grid may not reflect the water managers' needs, priorities or ways of thinking or categorizing even if they report to understand the matrix.

Thus, the application of the matrix may be more useful for distinguishing water managers' framings of uncertainty situations rather 
than for objectively classifying the uncertainty situations themselves.

\subsection{Characterization of uncertainties}

Beyond grasping uncertainty situations of water management through the UM, the way people frame uncertainty in water management practice can be characterized from different angles.

The Uncertainty Dialogues allowed for detecting differences in the water managers' framing of the uncertainties in various respects, rendering details on how the uncertainties were conceived by them. To assess these differences we analyzed the way in which the participants of the Uncertainty Dialogues reported on their examples of situations of uncertainty in water management.

The most pronounced parameters found through analyzing the Uncertainty Dialogues were: positioning, urgency, and issues of responsibility and trustworthiness. Often these parameters were interlinked and could not be looked at strictly separately. In the following they are illustrated along the examples from the case studies.

\section{Positioning}

The different kinds of positioning towards uncertainty situations we encountered in the Uncertainty Dialogues varied throughout the case studies and the participants of the dialogues. With positioning towards uncertainty we mean the evaluative quality people attach to the uncertainties, in other words whether they frame the uncertainty as something positive or negative (Levin, Schneider \& Gaeth 1998). This does not necessarily reflect deeper routed and more general beliefs and attitudes. These positive and negative framings of an uncertainty situation can have different manifestations, such as framings of uncertainty as risk, fun, challenge, essential part of life, threat etc. It may as well be quite ambiguous as an example in the Kromme Rijn case study shows. "Uncertainty has a little bit a negative connotation. Uncertainty, that's what you cannot grasp and that is an- 
noying" (NeWater Uncertainty Dialogue ${ }^{2}, \operatorname{HDSR}^{3}$, May 17, 2006); but then the speaker goes on that in fact her work is determined by uncertainties, "I live so to speak from uncertainties, and I enjoy it. The moment it gets certain it's not my work anymore" (ibidem). One interviewee in the Elbe case study takes up a similar stance. He is very enthusiastic about the element of water and the rivers since they do not care about political boundaries. He sees the related uncertainty as something vital to life, "I think that is the life. (...) and still there will be uncertainties. And to have a dream not to be [uncertain], wouldn't be life. That's life" (UJEP4, May 15, 2006). The same interviewee later makes another comment which maybe shows his enjoyment in dealing with uncertainties but certainly his experience of uncertainty as a challenge in the work area of water pollution, "уou must be very smart, sometimes it is a detective story, to detect the pollutant, or the polluter" (UJEP, May 15, 2006). Among the positive framings we encountered in the case studies the most frequent in fact was that uncertainty was framed as a challenge.

Throughout the dialogues the participants used terms other than 'uncertainty' as well to express situations that implied uncertainty. These terms may include a certain positioning towards the uncertainty situation, e.g. a negative framing. Terms that came up in several case studies in this regard were 'risk', 'doubt', 'problem' or 'difficulty'. Besides, a lot of other expressions which display uncertainties were used, not directly collated in a substantive however. Many of the examples were related to the issue of (not) knowing something, e.g. "I do not know if we are able to evaluate environmental costs" (CHG, May 25, 2006), "still you never know what will come" (UJEP, May 15, 2006), "probability of drought... but we do not know when it will happen. Even the meteorologists do not tell us" ( $\mathrm{CHG}^{5}$, May 25, 2006), and through making reference to the contrary of uncertainty, that is certainty, "the only certain thing is

\footnotetext{
${ }^{2}$ Where not referred to differently all further quotations from oral communication (with exact date) refer to the NeWater Uncertainty Dialogues and can be found in the references under Project NeWater meeting 'Uncertainty Dialogue'.

${ }^{3}$ Hoogheemraadschap De Stichtse Rijnlanden (Dutch regional water board)

${ }^{4}$ University of Jan Evangelista Purkyně, Usti nad Labem, Czech Republic

${ }^{5}$ Confederación Hidrográfica del Guadiana (Guadiana Water Authority)
} 
that some time the water pollution will come. You don't know where, you don't know which type, (...) which polluter, which amount (...) it is always an individual case", Elbe case study, about accidental water pollution by complex organic material (UJEP, May 15, 2006). Uncertainty was expressed with regard to rather technical issues, for instance concerning measuring systems in the Guadiana. The participants of the meeting were worried about not getting direct and accurate data from indirect measuring systems such as remote sensing (CHG, May 25, 2006). But also the political sphere was referred to: "the big part of the unpredictabilities is political. This is the total unpredictability" (ibidem).

In our case studies we observed a certain domination of negative framings though there were also some positive examples and other rather neutral ones that showed the acceptance of uncertainties as a fact without however really evaluating the uncertainty as positive or negative.

As pointed out earlier, the parameters often are interlinked. Positioning for instance also plays a role in connection with time frame "I just wanted to emphasize how difficult it is in the execution within a legal system to suddenly get the Water Framework Directive" (WV', May 18, 2006).

\section{Urgency}

The time factor seems to play an important role in all investigated case studies with regard to framing of uncertainties. Some uncertainties are framed as urgent, requiring an action within a short term, while others are framed as long-term issues, requiring attention in or over a few years of time. This may relate to the perceived urgency of a decision as well as to the time frame within which a decision will be implemented or is supposed to have an effect.

Concerning the time frame within which a decision has to be taken, lots of examples in the case studies showed that dealing with an uncertain situation would optimally require a lot of time. This is due to the fact that often more or more in depth analysis, model and

\footnotetext{
${ }^{6}$ Wupperverband (German water association)
} 
scenario building were considered as possible ways to reduce or overcome an uncertainty. In the case of accidental water pollution for instance this is increasing the uncertainty considerably since "to analyse the complex cyanide [i.e. its behaviour in the river waters after an accident] it is not so easy, it takes time" (UJEP, May 15, 2006) whereas decisions have to be taken in a relatively short time once an accident has happened. Especially in administrative planning, long-term considerations and goals most commonly have to be evaluated against short-term pressures. In the Wupper case study this is expressed with regard to the value and benefit of the ecosystems where the long-term goal is to secure them. “(...) On the other hand the decision is short-termed considering the financial straits we have in North-Rhine-Westphalia" (StUA7 Düsseldorf, May 18, 2006). The situation is difficult since "these time concerns are related with big uncertainty and as a planning administration I can only think in a long-term time frame" (ibidem). Another participant of the Wupper Uncertainty Dialogue frames the issue of current versus long-term planning in the following way: "To what extent do we manage to meet the zeitgeist of 20 years ahead with the decisions we take today and that will still be important in 20 years?" (municipality of Wuppertal, May 18, 2006).

An example of rather low urgency is the balancing of the economical versus the ecological and social benefits of an ecosystem in the Guadiana case study. They rather seem to play a role in the long run, "the maintenance of an ecosystem such as the Tablas de Daimiel against the economic or social benefit that may have the agricultural use - at a certain moment we will have to do this balance" (CHG, May 25, 2006).

\section{Responsibility}

Responsibility issues refer to different aspects around an uncertain situation. They may relate to the question of who is perceived as responsible for solving an uncertain situation and they also give an idea about the perceived range of options for actions and taking decisions in a situation marked by uncertainty.

\footnotetext{
${ }^{7}$ Staatliches Umweltamt (former German regional state authority for environment)
} 
In the dialogues, mainly the issue of who is responsible for dealing with an uncertainty situation came up. However, deducing from that it may be interesting to investigate who or what is perceived as responsible for having caused an uncertain situation. This may have implications in terms of who is perceived to be responsible for dealing with it as well as with regard to actual strategies for dealing with uncertainty. In the following, some examples from the case studies will illustrate how responsibilities got framed as part of dealing with uncertainty.

The question of responsibility for solving an uncertainty situation is quite delicate. The participants of the dialogues reported on themselves and other people to often refer to rules when taking a decision and thus to shift the responsibility to something rather external to them. Especially in administration, usually there are rules to be followed in an uncertain situation. This gets explicit for instance in the Wupper case study in the issue of flood protection, "the experts have developed state-of-the-art technology for a 100 year flood. Then the administration says, I have to meet the state-of-the-art technology" (WV, May 18, 2006). These regulations are then difficult to by-pass, "this [the regulation] is very difficult to turn back" (ibidem). So, administration generally needs to build its decisions on rules and regulations. Administration staff may consider stakeholders' suggestions but cannot build their decision on that. "If the citizen says I do not need this [measure; here dike] and in 15 years, if something really happens, and the citizen says, "so, now I claim damages", then this goes back to the administration and I think this really is an uncertainty that gets in the way of many things and also of sound solutions" (StUA Düsseldorf, May 18, 2006). An interviewee of the Guadiana case study points in the same direction for the case of the surveillance of ground water extraction in the catchment area, "the administration has to match the compliance of the law" (CHG, May 25, 2006), and makes similar references about the options for stakeholders influencing decisions of the state, "there is a limit which is the law" (ibidem). Consequently the solution is perceived in terms that the law should change, "if you want the situation to be changed then the law has to be changed in the parliament" (ibidem). Another example of the Guadiana basin is related to uncertainty related to drought. Decisions there are highly rule-based as 
well. There is a system of drought indicators consisting of different categories each of them implying a different level of alert and corresponding actions to take in that respective situation (CHG, May 25, 2006). So, in general following rules is adopted as a means to deal with the responsibility issue and thereby circumvent the uncertainty. Sometimes however, rules or regulations can be even more confusing and rather increase than decrease uncertainty as is the case for the implementation of the EU Directives on Nitrate and Water which partly are contradictory and hence difficult to implement in an integrated way (MLU S-A, May 22, 2006).

A big concern in terms of responsibility during the Uncertainty Dialogues was that the participants felt they do not have the final decision in a situation of uncertainty. The responsibility often is at a higher level than those of the interviewees in the dialogues, "(...) we are technicians. Technicians at a high level but we do not have the final decision" (CHG, May 25, 2006). This implies a high importance of communication and coordination among actors involved in one uncertainty situation.

In the Elbe case study, the interviewee points to the different roles of the actors involved. "They [from the International Commission for the Protection of the Elbe] only give recommendations. The implementation then is at national level" (UJEP, May 15, 2006). And "you have to discuss, to explain, but the final decision is on the delegates in Germany and the Czech Republic. But I mean that makes no problem. But as you said often the implementation is at the national level" (ibidem). Though, as can be seen from the quote the lack of decision-making power is not always seen as a problem.

Another aspect in (at least partly) getting around the responsibility for dealing with an uncertain situation which is showing from the previous example as well is that tasks usually are clearly distributed, "floods are not my field" (UJEP, May 15, 2006), or at least perceived as such. In the Guadiana case study, for certain issues politicians are perceived as in duty of taking a decision. The final decisions, e.g. on the issue of control of ground water extraction, are said to lie at the 'water commissar' from the Water Authority and the politicians in the region. "The ones who have to wipe off the mortgage are the politicians, through their political decision. A political decision based on the actual reality" (CHG, May 25, 2006). Talking 
about the case of threat of droughts due to climate change in the Guadiana case study the responsibilities are considered differently. For the case of estimations of future precipitations the responsibility is perceived to be at the level of the national climate change office (as part of the National Ministry of Environment), “(...) they are working out at the moment to define us what is the variation in the estimations" (CHG, May 25, 2006). For helping out with uncertainties due to lack of knowledge scientists are perceived as responsible in the first place, "with regard to the lack of knowledge (...) or the development of methodologies, technical systems, technologies etc.., this is a matter where there are you universities to help and investigate" (CHG, May 25, 2006).

In most examples in the investigated case studies the responsibility for dealing with uncertainty was shifted to others. That is the uncertainty gets framed as something where others are responsible for.

\section{Trustworthiness}

Parts of an uncertain situation, such as actors or data, are framed as trustworthy (or rather not). This relates to the quality of relationship of actors among each other as well as to the reliability of data, both being possible triggers for or against uncertainty. In some situations one could even say that the uncertainty in fact consists of the untrustworthiness itself.

There is evidence of the importance of trust towards certain information or people in all case studies, e.g. the Kromme Rijn: "Also the state has been an unreliable partner once when they had regulations for subsidies (...) and from one day to the next they were finished" (municipality Wijk-bij-Duurstede, May 17, 2006). This remark may be extended to collaborative work in general, though usually not referring to daily work, when one of the parties stops his commitment without notifying beforehand. Such behaviour may then be causing uncertainty (municipality Wijk-bij-Duurstede, October 16, 2007).

Concerning framing of trustworthiness of information, trust in data in the Guadiana case study for instance is high, amongst others because data are officially certified by the National Institute of Meteorology. Only in case of a wider time span, like in series of data, 
there could be some doubts, but in principle the data is considered as highly reliable. "The measuring [of precipitation] usually is direct and from relatively trustworthy data, (...) moreover it is officially certified data of the National Institute of Meteorology. They give us precipitation data; apart from the fact that we ourselves also have water meters. But (...) we trust them, (...) they are also from the existing official network and therefore deserve full guarantee. These data maybe may have errors (...) in a certain moment in the meteorological series, in the series of precipitation, but in principle they have full reliability" (CHG, May 25, 2006). Loss of trust as a risk for bad uncertainty management was expressed in the Kromme Rijn case study with regard to situations of possible negative side effects of plans during or after implementation, not having been taken into account as possible risks beforehand, as was the case in the working area of the interviewee: "The side effect might then be that (...) the trust in the state or the planners goes down" (municipality Wijk-bijDuurstede, May 17, 2006).

Framing of trustworthiness between actors or groups of actors is a delicate issue. It is an interesting issue as well in terms of who frames whom as trustworthy or not in a multi-actor constellation, most likely having implications for approaches how to deal with the uncertainty. Untrustworthiness in the form of prejudices or generalizations about actor groups may be manifested by confirmation biases. In the Uncertainty Dialogues this was displayed in several case studies through referring to other actors or actors groups as "them" and what "they do" rather than as individual actors and actions.

As shows the case of the Elbe on accidental water pollution, issues of organization and communication may aggravate or levy uncertainty, "there [in Czech Republic] is a lot of data [on accidental water pollution], it is very good. In Germany it's not so easy, because nobody tells you the proper information. Nobody collects centrally, in Czech Republic yes." (UJEP, May 15, 2006).

In general, the trustworthiness of data or people in the case studies shows to be highly dependent on previous experiences. 


\subsection{The third axis - A new dimension in the framing of uncertainty}

In the previous chapter we illustrated the most pronounced parameters that seem to play a role in how the participants of the Uncertainty Dialogues framed uncertainties. Uncertainty gets framed in terms of positioning as positive or negative, as an urgent or a longterm issue, as an issue for which the actor herself versus other actors are responsible and as untrustworthy (or not).

At all parameters the focus is on the relation of a person towards an uncertainty. The idea is not to assess objective boundary conditions but how people relate to those and to the possibly uncertain issues. Likewise, the use of the uncertainty matrix in the case studies has shown that allocation to the cells was not always easy because the allocation is not just an objective classification. Classifying rather tells something about how the person who is classifying frames the respective uncertainty.

Where the UM can be understood as a tool for a first assessment of framing of uncertainties through the additional parameters the character of an uncertainty may be captured.

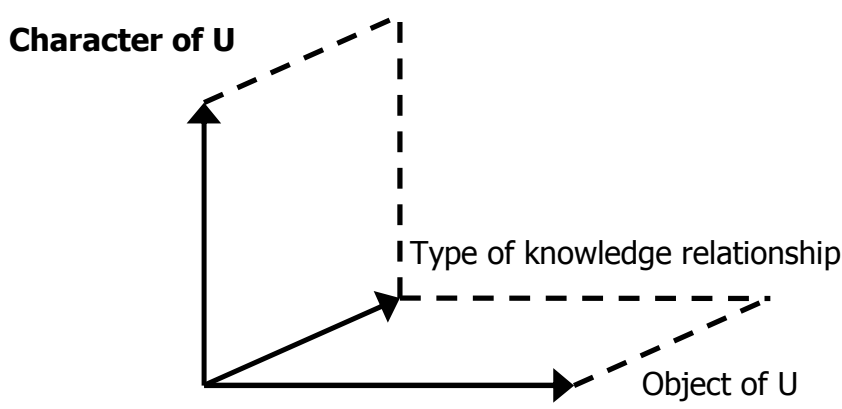

Figure 1: Three dimensions of uncertainty (U)

These parameters of the character of an uncertainty (PCU) can be seen as an extension of the matrix. We therefore suggest adding a third axis to the UM assembled by the PCU (see figure 1). By adding the PCU as a third axis or dimension additional aspects may be captured that are not possible to assess by the two-dimensional uncertainty matrix. The third dimension provides the option to further 
differentiate facets of the uncertainty situations that are captured by the UM.

Neither through the use of the UM nor with the help of the parameters of the character of an uncertainty situation it can be explained why an uncertainty situation is framed as it is but rather what is getting framed and how. The parameters may however have explanatory value for the evaluation of the strategies to deal with uncertainty.

\section{Conclusion}

Experiences from practical cases within the NeWater project show that uncertainties in water management are framed in different ways. In this paper we analyzed how practitioners in water management frame uncertainties by analyzing dialogues on uncertainty where water managers reported on their work experience with uncertainty. From the analysis we derived a set of parameters that seem to be important in the framing of uncertainties and illustrate the character of uncertainty (PCU). We also examined the options for using the uncertainty matrix (UM) as a tool for assessing the framing of uncertainties.

We have argued that analyzing the framing of the context where an uncertainty arises together with the way how the uncertainties are framed (through both the UM and the PCU) makes differences in the framing of an uncertainty situation visible. We thereby expect to obtain a basis for analysis and evaluation of strategies for dealing with uncertain situations. At the individual level, it may render a better picture of one's own action options including a clearer division of tasks as well as showing options for reframing. At the group level, focusing on interaction with other actors, it may make framings, priorities, and worries of others involved clear and reduce misunderstandings, thereby opening the option for reframing and negotiation.

However, the question is what is the best way to proceed in order to assess the framing of uncertainty and make it visible? We argued that using the UM for assessing framing of uncertainty implies an intervention in the assessment process and may therefore distort the findings considerably. The same would probably hold true if one 
tried to assess the PCU in a structured and systematic way. Adding the PCU as a third axis to the UM then rather implies an amplification of the matrix as a tool for ex post analysis than a means to further structure the assessment process. However, the identified dimensions (both UM and PCU) provide a set of potentially relevant aspects, whose relevance and relative importance can be assessed for a specific situation, and which can be complemented by contextual factors that is new, locally relevant dimensions in that specific situation.

An option in order to assess the framing of uncertainties of practitioners in water management in a less influenced way would be a less structured assessment approach. It may be interesting for instance to elicit parameters directly from the practitioners - rather than through ex post analysis. This could be done through card sorting techniques or similar (cf. e.g. Hare and Pahl-Wostl 2002) whereby participants themselves identify the parameters that have relevance for them.

\section{Acknowledgements}

The work presented in this paper was financially supported by the European Commission (Contract $\mathrm{N}^{\circ} 511179$ - NeWater).

We thank the participants of the Uncertainty Dialogues in the case studies of the Elbe, Guadiana, Kromme Rijn and Wupper for their kind collaboration and openness.

\section{References}

\section{Literature}

Brugnach et al. (2007). Towards a relational concept of uncertainty: about knowing too little, knowing too differently and accepting not to know. MOPAN Conference, June 28-29, 2007. Leuven, Belgium 
Dewulf et al. (2005). Disentangling approaches to framing: mapping the terrain. 18th IACM Conference, June 12-15, 2005. Sevilla, Spain

Gray, B. (2003). Framing of environmental disputes. Making sense of intractable environmental conflicts - frames and cases. R. Lewicki, B. Gray and M. Elliot. Washington, Covelo, London, Island Press.

Hare, M. and C. Pahl-Wostl (2002). Stakeholder Categorization in Participatory Integrated Assessment Processes. Integrated Assessment 3 (1): 50-62

Kickert, W. J. M., E.-H. Klijn, et al. (1997). Managing complex networks - strategies for the public sector, SAGE Publications Ltd.

Klauer and Brown (2004): Conceptualizing Imperfect Knowledge in Public Decision Making: Ignorance, Uncertainty, Error and Risk situations. Environmental Research, Engineering and Management 1(27): $124-128$

Levin, Schneider \& Gaeth (1998). All frames are not created equal, Organizational Behavior and Human Decision Processes. Vol. 76, No. 2, November, pp. 149-188, 1998

Pahl-Wostl, C., M. Craps, A. Dewulf, E. Mostert, D. Tabara, and T. Taillieu (2007). Social learning and water resources management. Ecology and Society 12(2): 5.

Schön, D. A. and M. Rein (1994). Frame reflection - toward the resolution of intractable policy controversies, Basic Books

van Asselt, M. and J. Rotmans (2000). Uncertainty in integrated assessment - A bridge over troubled water, ICIS (International Centre for Integrative Studies) Maastricht University: 60

Weick, K. (1995). Sensemaking in organizations. Thousand Oaks: Sage.

\section{Project documents (NeWater)}

NeWater internal report (2007). Uncertainty Dialogues

Project NeWater meeting "Uncertainty Dialogue" Elbe case study, May 22, 2006, 14h30 - 15h30, at the Ministry for Agriculture and Environment of Sachsen-Anhalt, Madgeburg, Germany. Title "Unsicherheitsdialog". Participant (besides moderators): Ministry for Agriculture and Environment of Sachsen-Anhalt (one member of staff) 
Project NeWater meeting "Uncertainty Dialogue" Elbe case study, 15 May 2006, 9-10 a.m., at Hotel Best Western Vladimir, Usti nad Labem, Czech Republic. Title "Uncertainty Dialogue“. Participant (besides moderators): University of Jan Evangelista Purkyně (UJEP) Usti nad Labem, member of the International Commission for the Protection of the Elbe, working group of accidental water pollution.

Project NeWater meeting "Uncertainty Dialogue" Guadiana case study, May 25, 2006, 9h30-11h a.m., at the Confederación Hidrográfica del Guadiana (Guadiana Regional Water Authority), Ciudad Real, Spain. Title "Diálogo de Incertidumbres". Participants (besides moderators): Confederación Hidrográfica del Guadiana (two members of staff). Citation translated from Spanish.

Project NeWater meeting "Uncertainty Dialogue" Kromme Rijn case study, May 17, 2006, 10-12 a.m., at the Hoogheemraadschap De Stichtse Rijnlanden, Houten, Netherlands. Title "Onzekerheidsdialoog". Participants (besides moderators): Hoogheemraadschap Stichtse Rijnlanden (one member of staff), Municipality of Houten (one member of staff), Municipality of Wijk-bij-Duurstede (one member of staff). Citation translated from Dutch.

Project NeWater meeting "Uncertainty Dialogue" Wupper case study, May 18, 2006, 10-12 a.m., at the Wupperverband in Wuppertal, Germany. Title "Unsicherheitsdialog". Participants (besides moderators): Wupperverband (three members of staff), municipality of Wuppertal (one member of staff), StUA Düsseldorf (one member of staff). Citation translated from German.

\section{E-mail communication}

Municipality Wijk-bij-Duurstede, October 16, 2007, on the follow-up of the citations of the Uncertainty Dialogue Kromme Rijn from May 2006, project NeWater. 